\title{
Urinary kallikrein activity in workers exposed to cadmium, lead, or mercury vapour
}

\author{
H A Roels, R R Lauwerys, J P Buchet, A M Bernard, P Lijnen, G Van Houte
}

\begin{abstract}
A significant reduction of kallikrein activity in urine (assayed by its amidolytic activity) was found in 64 normotensive workers who had been exposed to cadmium for 11 years on average and whose cadmium concentrations in urine ranged from $2 \cdot 2$ to $33 \cdot 1 \mu \mathrm{g} / \mathrm{g}$ creatinine. The mean (geometric) urinary kallikrein activity (in U/g creatinine) amounted to 0.52 (range 0.11-1.90) in the control group $(n=193)$ against 0.39 (range $0 \cdot 10-1.03$ ) in the cadmium group, and the prevalence of abnormally low activity levels $(\leqslant 0.20 \quad \mathrm{U} / \mathrm{g}$ creatinine $)$ amounted to $17 \cdot 2 \%$ in the cadmium group against $5 \cdot 2 \%$ in the control group. A reduction of aldosterone release (aldosterone in urine) associated with an increased natriuresis was also observed. This might constitute a compensatory mechanism maintaining blood pressure in the normal range. These biological effects of cadmium were not reversible after removal from exposure. This study indicates that cadmium can induce an irreversible toxic effect in the distal nephron. It also suggests that an excessive cadmium body burden alone may not be sufficient to induce hypertension, but in individuals whose blood pressure regulation may be impaired by other factors cadmium could stimulate the development of hypertension. This study also supports the recommendation to prevent hypertensive subjects from being exposed to cadmium. There was no indication that moderate exposure to mercury vapour $(n=53$; mercury in urine, range 11-224 $\mu \mathrm{g} / \mathrm{g}$ creatinine; average duration of exposure: six years) or to inorganic lead $(n=23$; lead in blood, range 40-67 $\mu \mathrm{g} / 100 \mathrm{ml}$; average duration of exposure: eight
\end{abstract}

\footnotetext{
Unité de Toxicologie Industrielle et Médecine du Travail, School of Medicine, Catholic University of Louvain, B-1200 Brussels, Belgium

H A Roels, R R Lauwerys, J P Buchet, A M Bernard, G Van Houte

Hypertension and Cardiovascular Rehabilitation Unit, Department of Pathophysiology, Campus Gasthuisberg, University of Leuven (KU Leuven) P Lijnen
}

years) was associated with a reduction of kallikrein production by the kidney.

The kidney occupies a key position in the regulation of blood pressure. Since it is also the target organ after excessive long term exposure to heavy metals such as cadmium $(\mathrm{Cd})$, mercury $(\mathrm{Hg})$, and lead $(\mathrm{Pb})$, several experimental and epidemiological studies have attempted to assess the possible aetiological role of heavy metals (particularly $\mathrm{Pb}$ and $\mathrm{Cd}$ ) in the pathogenesis of hypertension. It is generally agreed that long term exposure to $\mathrm{Pb}$ associated with clinical signs of intoxication may be a factor in the development of hypertension. ${ }^{1}$ But several studies on the possible influence of low level $\mathrm{Pb}$ or $\mathrm{Cd}$ exposure on blood pressure have provided conflicting results. ${ }^{2-9}$ This is not surprising since blood pressure control is complex and interference with one regulating mechanism may be neutralised by compensatory reactions. Hence, blood pressure measurement may not be a sufficiently sensitive index for the early detection of toxic interferences with blood pressure regulation. Since experimental studies have indicated that $\mathrm{Pb}$ and $\mathrm{Cd}$ might decrease the activity of the kallikrein kinin system, considered as an antihypertensive function of the kidney, ${ }^{10-13}$ we have measured the activity of kallikrein (EC 4.4.21.35) in the urine of workers exposed to heavy metals $(\mathrm{Cd}$, $\mathrm{Hg}$, or $\mathrm{Pb}$ ) who had normal blood pressure. In the $\mathrm{Cd}$ group and its corresponding control group the integrity of the prohypertensive renin angiotensin aldosterone system was also assessed by monitoring the urinary concentration of aldosterone. Electrolyte concentrations in plasma and in urine, creatinine and $\beta_{2}$-microglobulin in serum, and the urinary concentration of total proteins, aminoacids, and three proteins (albumin, retinol binding protein, $\beta_{2}$-microglobulin) were also measured.

\section{Subjects and methods}

STUDY POPULATION

The total study population comprised 419 male workers divided into 192 metal exposed and 227 control subjects. The group of exposed subjects consisted of three subgroups: (1) a Cd group of 97 workers exposed to $\mathrm{Cd}$ dust and fume in two $\mathrm{Cd}$ smelters (29 were already retired or removed from 
exposure at the time of the survey); (2) a $\mathrm{Hg}$ group of 58 workers currently exposed to $\mathrm{Hg}$ vapour (chloralkali plant, manufacture of alkaline batteries), and (3) a $\mathrm{Pb}$ group of 37 workers currently exposed to $\mathrm{Pb}$ dust and fume ( $\mathrm{Pb}$ smelter, ceramic manufacturing plant).

The definitive selection of the study population was based on the results of biological analyses and clinical examination at the time of the survey and on information gathered by a questionnaire mainly related to medical and occupational history.

The following criteria were adopted:

(1) The control subjects had never been occupationally exposed to $\mathrm{Cd}, \mathrm{Pb}$, or $\mathrm{Hg}$ and at the time of the survey their concentrations of lead $(\mathrm{PbB})$ in blood, and of cadmium (CdU) and mercury $(\mathrm{HgU})$ in urine were normal-that is, $\mathrm{PbB}<35 \mu \mathrm{g} / 100 \mathrm{ml}$, CdU $<2 \mu \mathrm{g} / \mathrm{g}$ creatinine, and $\mathrm{HgU}<5 \mu \mathrm{g} / \mathrm{g}$ creatinine.

(2) The exposed workers should have been uninterruptedly exposed either to $\mathrm{Cd}$, or $\mathrm{Pb}$, or $\mathbf{H g}$ vapour, for at least one year before the study and at the time of the examination the following biological criteria had to be fulfilled:

Cd group: CdU $\geqslant 2 \mu \mathrm{g} / \mathrm{g}$ creatinine, $\mathrm{PbB}<35 \mu \mathrm{g} /$ $100 \mathrm{ml}, \mathrm{HgU}<5 \mu \mathrm{g} / \mathrm{g}$ creatinine

$\mathrm{Pb}$ group: $\mathrm{PbB} \geqslant 35 \mu \mathrm{g} / 100 \mathrm{ml}, \mathrm{CdU}<2 \mu \mathrm{g} / \mathrm{g}$ creatinine, $\mathrm{HgU}<5 \mu \mathrm{g} / \mathrm{g}$ creatinine

$\mathrm{Hg}$ group: $\mathrm{HgU} \geqslant 5 \mu \mathrm{g} / \mathrm{g}$ creatinine, $\mathrm{PbB}<35 \mu \mathrm{g} /$

$100 \mathrm{ml}, \mathrm{CdU}<2 \mu \mathrm{g} / \mathrm{g}$ creatinine.

(3) The medical history of the control and exposed workers should not show cardiovascular diseases such as hypertension or coronary insufficiency, kidney diseases of known causes-for example, renal stones or congenital abnormalities-or diabetes mellitus.

(4) Subjects on a sodium poor diet, as reflected by a low urinary concentration of $\mathrm{Na}^{+}(<35 \mathrm{mmol} / \mathrm{g}$ creatinine, corresponding to a natriuresis $<50$ $\mathrm{mmol} / 24 \mathrm{~h}$ ), were excluded since an abnormally low intake of sodium may be associated with a pronounced increase of urinary kallikrein activity. ${ }^{14}$

Thirty four control workers (seven with excessive exposure to heavy metals, 13 with health problems, and 14 with low urinary sodium) and 52 metal exposed workers (40 with mixed occupational exposure to heavy metals, six with health problems, and six with low urinary sodium) did not meet these selection criteria and were excluded from the definitive study population that comprised 333 subjects subdivided into a group of 193 control workers, a Cd group of 64 subjects (40 currently exposed and 24 removed from exposure), a $\mathrm{Hg}$ group of 53 subjects, and $\mathrm{ab}$ group of 23 subjects.

BLOOD AND URINE SAMPLING

At the time of examination a sample of venous blood $(20 \mathrm{ml})$ and a spot urine sample $(50 \mathrm{ml})$ were collected from each participant. Syringes, tubes, and urine containers were previously checked for lack of hea metal contamination. Blood samples were divided as follows: $5 \mathrm{ml}$ were transferred to a polyethylene tubge (containing $50 \mu \mathrm{l} \mathrm{Na} \mathrm{N}_{2}$-EDTA, 10\% w/v) for heavy metal analysis and the remainder was kept in $\overline{\text { m }}$ empty tube for separation of serum. The bloged samples were kept at $4^{\circ} \mathrm{C}$ and the serum samples $\mathrm{gt}$ $-20^{\circ} \mathrm{C}$. Immediately after the urine samples were obtained an aliquot of $4 \mathrm{ml}$ was transferred to a tube containing $0.4 \mathrm{ml}$ phosphate buffer $1 \mathrm{~mol} / \mathrm{l}, \mathrm{pH} 7.6$ (containing $0.2 \% \mathrm{NaN}_{3}$ ) and kept at $-20^{\circ} \mathrm{C}$ until the analysis of $\beta_{2}$-microglobulin, retinol binding protein and albumin; another urine aliquot of $6 \mathrm{ml}$ was ke $\mathrm{gt}$ at $-20^{\circ} \mathrm{C}$ without preservative until the measurement of kallikrein activity and the concentration sodium; the remainder of the spot urine sample was kept at $4^{\circ} \mathrm{C}$ for subsequent analysis of heavy metaks, total proteinuria, and total aminoaciduria.

\section{BIOLOGICAL ANALYSES}

The internal exposure to the metals was assessed measuring $\mathrm{CdU}, \mathrm{HgU}, \mathrm{PbB}$, and zinc protoporphyrin in erythrocytes (ZPP) according to standaodised techniques. ${ }^{15-17}$ The following were measure\&, in serum: creatinine by the method of Heinegard and Tiderströ ${ }^{18}$ slightly modified for automation and $\beta_{2}$-microglobulin by latex immunoassay ${ }^{19}$; and in urine: creatinine, ${ }^{20}$ total proteins, ${ }^{21}$ aminoacids, ${ }^{15}$ 㞓microglobulin, retinol binding protein, and album by latex immunoassay, ${ }^{19}$ and sodium $\left(\mathrm{Na}^{+}-\mathrm{U}\right)$ By flame atomic absorption. ${ }^{22}$

The activity of kallikrein in urine was measured on an aliquot of the urine sample kept at $-20^{\circ} \mathrm{C}$ for not longer than 30 days, since decrease $(>5 \%)$ in urinary kallikrein activity occurs after a longer storafe period. The enzyme assay is based on the amidolytic property of this protease using as substrate, the chromogenic tripeptide H-D-valyl-L-leucyl-t:arginine-p-nitroanilide (S-2266) purchased froogn Kabi Diagnostica (Stockholm, Sweden). The assäy was carried out at $37^{\circ} \mathrm{C}$ in Tris- $\mathrm{HCl}$ buffer $(0.2 \mathrm{mgl} /$ $1, \mathrm{pH} 8.2$ ) according to the end point method described by Bönner and Marin-Grez. ${ }^{23}$ Preliminainy assays have shown that the final concentration rof aprotinin (Trasylol, Bayer, Leverkusen, FRG) in the assay mixture should be 100 instead of $10 \mathrm{KIU} / \mathrm{ml}$ tat obtain more than $95 \%$ inhibition of kallikrejn activity in the blank assay. For assays yielding absorbance increase at $405 \mathrm{~nm}$ higher than $0 \cdot 120$ / $30 \mathrm{~min}$, a diluted (two or fourfold) urine aliquot wes used. It is known that the metals have no diret inhibitory effect ${ }^{13}$ on kallikrein activity, at least in the range of concentrations found in the urine exposed workers.

In the 64 cadmium workers and in a subgroup of 7 age matched control subjects the serum concentrtions of $\mathrm{Na}^{+}$and $\mathrm{K}^{+}$were determined by flame atomic absorption ${ }^{22}$ and the concentration of uringefy 
Table 1 Characteristics of the groups

\begin{tabular}{|c|c|c|c|c|}
\hline Index & Control $(n=193)$ & $\operatorname{Cadmium}(n=64)$ & Mercury $(n=53)$ & Lead $(n=23)$ \\
\hline $\begin{array}{l}\underset{\text { Age }(y)}{\text { Mean }} \pm S E \\
\overrightarrow{\mathbf{x} g} \\
\text { Range }\end{array}$ & $\begin{array}{l}40 \cdot 5 \pm 0 \cdot 7 \\
39 \cdot 1 \\
21-69\end{array}$ & $\begin{array}{l}48 \cdot 9 \pm 1 \cdot 3 \\
47 \cdot 8 \\
30-69\end{array}$ & $\begin{array}{l}34 \cdot 8 \pm 1 \cdot 3 \\
33 \cdot 6 \\
20-57\end{array}$ & $\begin{array}{l}37 \cdot 2 \pm 2 \cdot 0 \\
36 \cdot 0 \\
21-54\end{array}$ \\
\hline $\begin{array}{l}\text { Duration of exposure (y) } \\
\text { Mean } \pm \mathrm{SE} \\
\overline{\mathbf{x} g} \\
\text { Range }\end{array}$ & - & $\begin{array}{l}15 \cdot 3 \pm 1 \cdot 4 \\
10 \cdot 8 \\
1-40\end{array}$ & $\begin{array}{l}7 \cdot 8 \pm 0 \cdot 7 \\
6 \cdot 1 \\
1-20\end{array}$ & $\begin{array}{l}9 \cdot 8 \pm 1 \cdot 2 \\
8 \cdot 1 \\
3-25\end{array}$ \\
\hline $\begin{array}{l}\text { CdU }(\mu \mathrm{g} / \mathrm{g} \text { creatinine }) \\
\text { Mean } \pm \mathrm{SE} \\
\overline{\mathbf{x g}} \\
\text { Range }\end{array}$ & $\begin{array}{l}0.64 \pm 0.03 \\
0.51 \\
0.1-1.9\end{array}$ & $\begin{array}{l}10 \cdot 4 \pm 0 \cdot 8 \\
8 \cdot 8 \\
2 \cdot 2-33 \cdot 1\end{array}$ & $\begin{array}{l}0.47 \pm 0.04 \\
0.41 \\
0.1-1.3\end{array}$ & $\begin{array}{l}1 \cdot 12 \pm 0.1 \\
1.01 \\
0.5-1.9\end{array}$ \\
\hline $\begin{array}{l}\text { HgU }(\mu \mathrm{g} / \mathrm{g} \text { creatinine }) \\
\text { Mean } \pm \mathrm{SE} \\
\overline{\mathbf{x g}} \\
\text { Range }\end{array}$ & $\begin{array}{l}1 \cdot 3 \pm 0 \cdot 1 \\
1 \cdot 0 \\
0 \cdot 2-4.9\end{array}$ & $\begin{array}{l}1 \cdot 0 \pm 0 \cdot 1 \\
0 \cdot 8 \\
0 \cdot 2-4.9\end{array}$ & $\begin{array}{l}74 \cdot 0 \pm 6 \cdot 4 \\
61 \cdot 5 \\
11 \cdot 3-224\end{array}$ & $\begin{array}{l}1.4 \pm 0.1 \\
1.3 \\
0.5-3.8\end{array}$ \\
\hline $\begin{array}{l}\mathrm{PbB}(\mu \mathrm{g} / 100 \mathrm{ml}) \\
\text { Mean } \pm \mathrm{SE} \\
\overline{\mathbf{x g}} \\
\text { Range }\end{array}$ & $\begin{array}{l}11 \cdot 9 \pm 0.4 \\
11 \cdot 0 \\
5 \cdot 1-33 \cdot 1\end{array}$ & $\begin{array}{l}22.1 \pm 0.7 \\
21.3 \\
11.4-33.9\end{array}$ & $\begin{array}{l}10 \cdot 0 \pm 0.6 \\
9 \cdot 3 \\
4 \cdot 9-27 \cdot 7\end{array}$ & $\begin{array}{l}51 \cdot 6 \pm 1 \cdot 6 \\
51 \cdot 1 \\
39 \cdot 5-66.6\end{array}$ \\
\hline $\begin{array}{l}\mathrm{ZPP}(\mu \mathrm{g} / \mathrm{g} \mathrm{Hb}) \\
\text { Mean } \pm \mathrm{SE} \\
\overline{\mathbf{x}} \mathbf{g} \\
\text { Range }\end{array}$ & $\begin{array}{l}1 \cdot 1 \pm 0.02 \\
1 \cdot 1 \\
0 \cdot 5-2 \cdot 4\end{array}$ & $\begin{array}{l}1.4 \pm 0.06 \\
1.3 \\
0.7-2.8\end{array}$ & $\begin{array}{l}1.3 \pm 0.04 \\
1.2 \\
0.7-2.2\end{array}$ & $\begin{array}{l}7 \cdot 9 \pm 1 \cdot 1 \\
6 \cdot 6 \\
2 \cdot 6-27 \cdot 1\end{array}$ \\
\hline
\end{tabular}

$\mathrm{SE}=$ Standard error of mean.

$\overline{\mathbf{x}} \mathbf{g}=$ Geometric mean.

aldosterone was measured in the $6 \mathrm{ml}$ urine aliquot by radioimmunoassay. ${ }^{24}$

\section{STATISTICAL ANALYSIS}

For uniformity of presentation of the results the variables were characterised by the arithmetic mean and standard error of mean, the geometric mean, and range. Student's $t$ test (two tailed) for unpaired data was used to compare group means. Pearson's and Spearman's (rank) correlation coefficients were calculated for the assessment of the associations between variables. Those variables that were not normally distributed (urinary cadmium and mercury levels, blood lead concentration, urinary kallikrein activity, aldosterone and sodium concentration in urine) were log transformed before the application of parametric analysis. The prevalences of abnormally low levels of urinary kallikrein activity were compared between groups using the Yates corrected $2 \times 2 \chi^{2}$ test or the $2 \times 4 \chi^{2}$ test. The lowest normal value of urinary kallikrein activity was taken as the fifth percentile of its distribution in the control group $(0.20 \mathrm{U} / \mathrm{g}$ creatinine). To ascertain the effect of exposure to cadmium on some variables (including urinary kallikrein activity and urinary sodium concentration), one or two way analyses of variance were performed between different groups after the variables were either log transformed or transformed into ranks on which parametric statistical analyses were applied as described in SAS procedures..$^{25}$ For all tests, $p<0.05$ was considered as the level of statistical significance.

\section{Results}

The characteristics of the groups are summarised in table 1 . Since some of the variables are log normally distributed, the geometric means are also given. It may be noticed that despite the selection criteria defined above, the $\mathrm{Cd}$ group was more exposed to $\mathrm{Pb}$ (as reflected by $\mathrm{PbB}$ ) than the control group and the $\mathrm{Pb}$ group had a $\mathrm{Cd}$ body burden (as reflected by $\mathrm{CdU}$ ) higher than the control group. Only the $\mathbf{H g}$ group had not sustained a mixed exposure; its internal dose of $\mathrm{Pb}$ and $\mathrm{Cd}$ did not significantly differ from that of the control group. Except in the Cd group (see below) the renal parameters (creatinine and $\beta_{2}$-microglobulin in serum and total proteins, aminoacids, $\beta_{2}$-microglobulin, and retinol binding protein in urine) were in the normal range in the other groups (results not shown).

The average urinary kallikrein activities found in the different subgroups are compared in table 2. A two way analysis of variance did not show any effect of age and natriuresis on urinary kallikrein activity in the control group. A one way analysis of variance on ranks showed that the kallikrein activity in urine was only significantly lower in the Cd group by comparison with the control group. The prevalence of abnormally low values of urinary kallikrein activity was significantly higher in the Cd group (17.2\%) than in the control group ( $\chi^{2}$ test: $\left.\mathrm{p}<0.05\right)$. The prevalence of abnormal levels of urinary kallikrein did not significantly differ in the $\mathrm{Hg}$ and the $\mathrm{Pb}$ groups compared with the control population (table 3). 
Table 2 Urinary kallikrein activity (U/g creatinine) in the different groups

\begin{tabular}{lclll}
\hline & $\begin{array}{l}\text { Control } \\
(n=193)\end{array}$ & $\begin{array}{l}\text { Cadmium } \\
(n=64)\end{array}$ & $\begin{array}{l}\text { Mercury } \\
(n=53)\end{array}$ & $\begin{array}{l}\text { Lead } \\
(n=23)\end{array}$ \\
\hline Mean \pm & SE $0.61 \pm 0.02$ & $0.46 \pm 0.03$ & $0.60 \pm 0.04$ & $0.52 \pm 0.06$ \\
Median & 0.55 & 0.42 & 0.53 & 0.44 \\
$\mathbf{x} g$ & 0.52 & 0.39 & 0.53 & 0.45 \\
Range & $0.11-1.90$ & $0.10-1.03$ & $0.11-1.66$ & $0.14-1.16$ \\
\hline
\end{tabular}

$\overline{\mathbf{x}} \mathrm{g}=$ Geometric mean

*Duncan's multiple range test on means of rank values: statistically significant difference $(p<0.05)$ for cadmium group compared with control group.

Since the $\mathrm{Pb}$ and $\mathrm{Cd}$ groups had sustained a mixed exposure, a possible interaction between both metals on renal kallikrein excretion could not be excluded on the basis of the above statistical analysis.

Therefore, the total population was subdivided into four subgroups on the basis of CdU ( $\leqslant$ and $>$ $1.5 \mu \mathrm{g} / \mathrm{g}$ creatinine) and $\mathrm{PbB}$ ( $\leqslant$ and $>21.8 \mu \mathrm{g} / 100$ $\mathrm{ml})$. These cutting points represent the 95 th percentile values of both parameters in the control population. A two way variance analysis on ranks (table 4) showed that only exposure to Cd was associated with a decreased level of urinary kallikrein activity and there was no interaction between $\mathrm{Pb}$ and $\mathrm{Cd}$ exposures. Again on the basis of the same biological criteria of exposure, the prevalence of low values of urinary kallikrein activity was only significantly increased in workers with increased Cd body burden (table 5). These findings are fully corroborated when taking ZPP instead of $\mathrm{PbB}$ as indicator of internal lead exposure.

We have also examined whether the urinary kallikrein activity significantly differed between the 46 $\mathrm{Cd}$ workers without signs of renal dysfunction and
Table 3 Comparison of the prevalence of abnormally low levels ${ }^{\star}$ of urinary kallikrein activity between the various groups

\begin{tabular}{|c|c|c|c|c|}
\hline $\begin{array}{l}\text { Urinary } \\
\text { kallikrein } \\
\text { (U/g creat) }\end{array}$ & Control & Cadmium & Mercury & Lead \\
\hline $\begin{array}{l}>0.20 \\
\leqslant 0.20\end{array}$ & $\begin{array}{l}183 \\
10(5 \cdot 2 \%)\end{array}$ & $\begin{array}{l}53 \\
11(17 \cdot 2 \%)\end{array}$ & $\begin{array}{l}50 \\
3(5 \cdot 7 \%)\end{array}$ & 22 \\
\hline
\end{tabular}

$\chi^{2}$ test $(2 \times 4): p<0.05 ; \chi^{2}$ test $(2 \times 2)$ between control and cadmium groups: $\mathrm{p}=0.002$.

$\star$ For definition一 -see text.

the 18 with increased urinary excretion of $\beta_{2}-\stackrel{\odot}{\Phi}$ microglobulin ( $>300 \mu \mathrm{g} / \mathrm{g}$ creatinine) or retinol 3 binding protein ( $>300 \mu \mathrm{g} / \mathrm{g}$ creatinine) or albumin $\hat{V}$ (>15 mg/g creatinine), or a combination of these.ir The latter had a lower average (geometric mean) $)_{\omega}^{\omega}$ urinary activity of kallikrein $(0.33 \mathrm{U} / \mathrm{g}$ creatinine $) \vec{\overrightarrow{ }}$ than the former $(0.42 \mathrm{U} / \mathrm{g}$ creatinine) but the difference did not reach the level of statistical sig- $\vec{z}$ nificance ( $t$ test: $\mathrm{p}>0.05$ ).

Since 24 hour urine collections could not be obtained, we must be cautious in interpreting the results of electrolyte excretion. Nevertheless, it is. interesting to notice that after standardisation for creatinine concentration, a one way parametric analysis of variance has shown that the level of $\mathrm{Na}^{+}$in urine (log normal distribution) was statistically higher (Duncan's multiple range test; $p<0.001$ ) in $\bar{Q}$ the Cd group ( $\overline{\mathbf{x} g: 1} 116.8 \mathrm{mmol} / \mathrm{g}$ creatinine; range: 43.2-266.7 mmol $/ \mathrm{g}$ creatinine) than in the controlo subjects ( $\overline{x g}: 89.5 \mathrm{mmol} / \mathrm{g}$ creatinine; range: $35 \cdot 3-$ $280.2 \mathrm{mmol} / \mathrm{g}$ creatinine). The urinary concentrations of $\mathrm{Na}^{+}$in the $\mathrm{Hg}$ group $(\overline{\mathrm{x} g}: 92.0 \mathrm{mmol} / \mathrm{g}$ creatinine; range: $39 \cdot 2-245 \cdot 8 \mathrm{mmol} / \mathrm{g}$ creatinine) andब the $\mathrm{Pb}$ group $(\overline{\mathbf{x}} \mathrm{g}: 83.6 \mathrm{mmol} / \mathrm{g}$ creatinine; range:

Table 4 Level of urinary kallikrein activity as a function of cadmium in urine and lead in blood

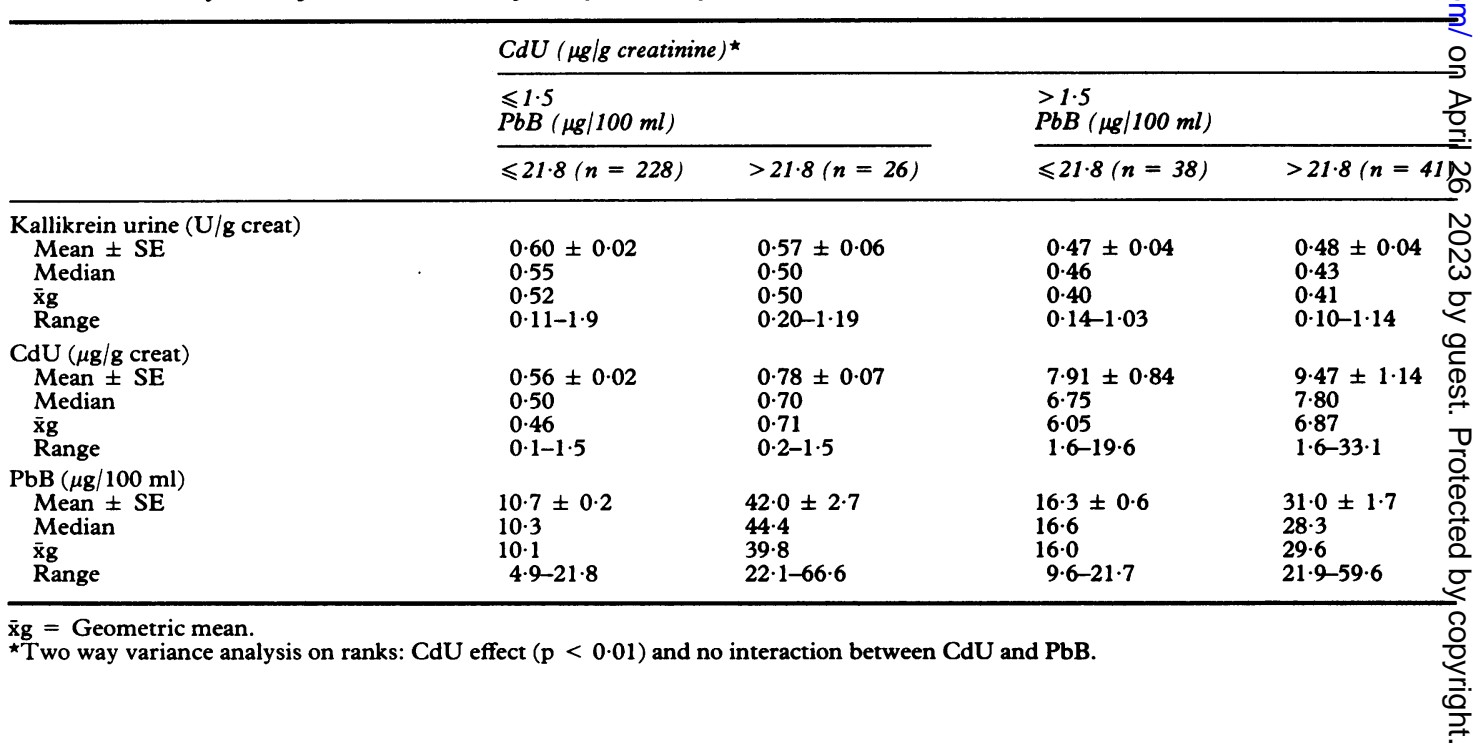


Table 5 Prevalence of abnormally low levels $\star$ of urinary kallikrein activity as a function of cadmium in urine and lead in blood

\begin{tabular}{|c|c|c|c|c|}
\hline \multirow{3}{*}{$\begin{array}{l}\text { Urinary } \\
\text { kallikrein } \\
\text { (U/g creat) }\end{array}$} & \multicolumn{4}{|c|}{$C d U(\mu g / g$ creatinine $)$} \\
\hline & \multicolumn{2}{|c|}{$\begin{array}{l}\leqslant 1 \cdot 5 \\
\operatorname{PbB}(\mu \mathrm{g} / 100 \mathrm{ml})\end{array}$} & \multicolumn{2}{|c|}{$\begin{array}{l}>1 \cdot 5 \\
P b B(\mu g / 100 \mathrm{ml})\end{array}$} \\
\hline & $\leqslant 21 \cdot 8$ & $>21 \cdot 8$ & $\leqslant 21 \cdot 8$ & $>21 \cdot 8$ \\
\hline $\begin{array}{l}>0.20 \\
\leqslant 0.20\end{array}$ & $216(5.3 \%)$ & 25 & ${ }^{32} 6(15 \cdot 8 \%)$ & ${ }^{35} 6(14 \cdot 6 \%)$ \\
\hline
\end{tabular}

$\chi^{2}$ test $(2 \times 4): \mathrm{p}<0.05$.

${ }_{\star}^{\star}$ For definition: see text.

40.7-284.8 $\mathrm{mmol} / \mathrm{g}$ creatinine) did not differ from that found in the control workers. Subdivision of the total population according to $\mathrm{CdU}$ and $\mathrm{PbB}$ confirmed that the increased urinary concentration of $\mathrm{Na}^{+}$was exclusively associated with the increased $\mathrm{Cd}$ body burden and again no interaction between exposures to $\mathrm{Pb}$ and $\mathrm{Cd}$ was found (table 6).

The urinary aldosterone concentration was significantly lower in the Cd group than in the age matched control workers (table 7). This was associated with a statistically significant increase of the serum $\mathrm{K}^{+}$level and a significantly decreased serum $\mathrm{Na}^{+}$concentration. The biological changes observed in cadmium workers did not significantly differ between those currently exposed or removed from exposure (table 8). The cadmium workers were also subdivided in two subgroups according to the presence or absence of an increased microproteinuria (as defined above) or on the basis of $\mathrm{PbB}$ ( $\leqslant$ and $>21.8 \mu \mathrm{g} / 100 \mathrm{ml}$ ). The urine aldosterone and the serum electrolyte concentrations did not differ between the subgroups (results not shown). A low but highly statistically significant Pearson correlation coefficient $(n=121$ : Cd group + age matched control group) was found between the urinary kallikrein activity and urinary aldosterone concentration ( $\log$ normal distributions: $r=0.33, p<0.001)$. No statistically significant rank correlation was found, however, between kallikrein activity or aldosterone concentrations in urine and duration of exposure to Cd or CdU.
Table 7 Concentration of aldosterone in urine and potassium and sodium in serum in workers exposed to cadmium and age matched control workers

\begin{tabular}{|c|c|c|c|}
\hline Index & $\begin{array}{l}\text { Control } \\
\text { workers } \\
(n=57)\end{array}$ & $\begin{array}{l}\text { Cadmium } \\
\text { workers } \\
(n=64)\end{array}$ & $p^{\star}$ \\
\hline $\begin{array}{l}\text { Age }(y) \\
\text { Mean } \pm S E \\
\text { Median } \\
\overline{\mathbf{x}} \mathbf{g}\end{array}$ & $\begin{array}{l}45 \cdot 9 \pm 1 \cdot 2 \\
47 \\
45 \cdot 1\end{array}$ & $\begin{array}{l}48 \cdot 9 \pm 1 \cdot 3 \\
49 \\
47 \cdot 8\end{array}$ & NS \\
\hline $\begin{array}{l}\text { Aldosterone urine }(\mu \mathrm{g} / \\
\text { creat) } \\
\text { Mean } \pm \mathrm{SE} \\
\text { Median } \\
\overline{\mathbf{x}} \mathbf{g}\end{array}$ & $\begin{array}{l}4.91 \pm 0.4 \\
4.03 \\
4.31\end{array}$ & $\begin{array}{l}3.63 \pm 0.2 \\
3.43 \\
3 \cdot 26\end{array}$ & $<0.005$ \\
\hline $\begin{array}{l}\mathrm{K}^{+} \text {-serum }(\mathrm{mmol} / \mathrm{l}) \\
\text { Mean } \pm \mathrm{SE} \\
\text { Median } \\
\overline{\mathbf{x} g}\end{array}$ & $\begin{array}{l}4 \cdot 53 \pm 0 \cdot 1 \\
4 \cdot 34 \\
4 \cdot 47\end{array}$ & $\begin{array}{l}6 \cdot 46 \pm 0 \cdot 1 \\
6 \cdot 38 \\
6 \cdot 42\end{array}$ & $<0.0001$ \\
\hline $\begin{array}{l}\mathrm{Na}^{+}-\operatorname{serum}(\mathrm{mmol} / \mathrm{l}) \\
\text { Mean } \pm \mathrm{SE} \\
\text { Median } \\
\overline{\mathbf{x g}}\end{array}$ & $\begin{array}{l}138.2 \pm 0.6 \\
138.8 \\
138 \cdot 1\end{array}$ & $\begin{array}{l}134.4 \pm 0.6 \\
133.4 \\
134.3\end{array}$ & $<0.0001$ \\
\hline
\end{tabular}

$\overline{\mathbf{x}} \mathbf{g}=$ Geometric mean.

$\star$ Student's $t$ test.

†Kallikrein urine $(\overline{\mathbf{x}} \mathbf{g})=0.54$ (U/g creat).

\section{Discussion}

Renal kallikrein, a serine protease that liberates the decapeptide lysylbradykinin (kallidin) from the plasma protein kininogen, is synthesised by the distal part of the nephron ${ }^{26}$ and is released into the urine. The activity of the renal kallikrein kinin system has usually been assessed in man and animals by measuring urinary kallikrein excretion.

The present study shows that workers exposed to Cd on average for 10 years had a significantly lower kallikrein concentration in urine than control subjects. This suggests that an increased $\mathrm{Cd}$ body burden may not only interfere with the function of the proximal tubule and the glomerulus but may also affect the distal nephron. Our observation on workers agrees with that of other investigators on rats chronically intoxicated with $\mathrm{Cd} .{ }^{11}{ }^{13}$ The effect of $\mathrm{Cd}$ on kallikrein production may occur independently of the presence of functional changes in the proximal tubule, since a statistically significant decreased urinary kallikrein activity was also found in the

Table 6 Sodium concentration in urine (mmol/g creatinine) as a function of cadmium in urine and lead in blood

\begin{tabular}{|c|c|c|c|c|}
\hline & \multicolumn{4}{|c|}{$C d U(\mu g / g$ creatinine) } \\
\hline & \multicolumn{2}{|l|}{$\begin{array}{l}\leqslant 1 \cdot 5 \\
P b B(\mu g / 100 \mathrm{ml})\end{array}$} & \multicolumn{2}{|l|}{$\begin{array}{l}>1 \cdot 5 \\
P b B(\mu g / 100 \mathrm{ml})\end{array}$} \\
\hline & $\leqslant 21 \cdot 8(n=228)$ & $>21 \cdot 8(n=26)$ & $\leqslant 21 \cdot 8(n=38)$ & $>21 \cdot 8(n=41)$ \\
\hline $\begin{array}{l}\text { Mean } \pm \text { SE } \\
\text { Median } \\
\overline{\mathbf{x}} \mathbf{g} \\
\text { Range }\end{array}$ & $\begin{array}{l}98 \cdot 8 \pm 3 \cdot 1 \\
87 \cdot 9 \\
88 \cdot 9 \\
35 \cdot 3-280 \cdot 2\end{array}$ & $\begin{array}{l}91 \cdot 2 \pm 7 \cdot 3 \\
86 \cdot 9 \\
84 \cdot 4 \\
40 \cdot 7-202 \cdot 7\end{array}$ & $\begin{array}{l}125 \cdot 2 \pm 7 \cdot 9 \\
120 \cdot 1 \\
115 \cdot 6^{\star} \\
43 \cdot 2-241.5\end{array}$ & $\begin{array}{l}129 \cdot 7 \pm 10 \cdot 2 \\
112 \cdot 3 \\
114 \cdot 6^{\star} \\
46 \cdot 3-284 \cdot 8\end{array}$ \\
\hline
\end{tabular}

$\overline{\mathbf{x}} \mathbf{g}$ : Geometric mean.

ఓTwo way variance analysis on log values and Duncan's multiple range test showed a CdU effect $(p=0.0002)$ and no interaction between $\mathrm{CdU}$ and $\mathrm{PbB}$. 
Table 8 Comparison of urinary kallikrein activity and aldosterone concentration in urine, and potassium and sodium concentration in serum in cadmium workers currently exposed or removed from exposure

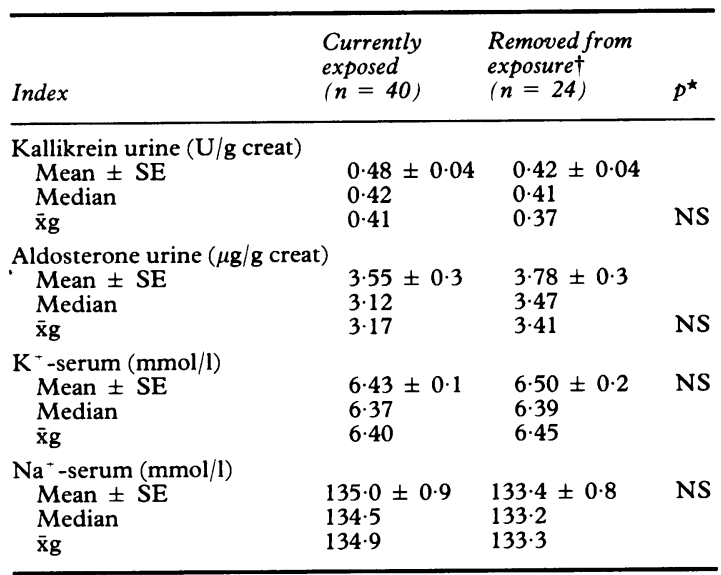

$\overrightarrow{\mathrm{x} g}=$ Geometric mean.

$\star$ Student's $t$ test.

+Duration: $1-17 \mathrm{~g}$ (6.7 $\mathrm{g}$ on average).

subgroup of Cd workers without microproteinuria. Despite the fact that no correlation was found between urinary kallikrein activity and $\mathrm{CdU}$, the effect of Cd at the distal nephron level seems to result from the increased Cd body burden and not from a concomitant exposure to $\mathrm{Pb}$. This effect is irreversible since the urinary kallikrein concentration remains low after removal from exposure to $\mathrm{Cd}$.

To be included in the present study, the workers had to have a normal blood pressure without medical treatment. Our results suggest that despite their reduced production of kallikrein, the Cd workers maintained their blood pressure in the normal range by stimulating a compensatory reaction, the reduction of aldosterone production (as reflected by urinary aldosterone) which led to an increased urinary excretion of sodium and an increased serum concentration of potassium. This is supported by the finding of a statistically significant correlation between the urinary kallikrein activity and urinary aldosterone concentration. Öhman and Karlberg also reported that in normal subjects, urinary kallikrein and aldosterone are usually related, suggesting a functional relationship between the two. ${ }^{28}$ In $\mathrm{Cd}$ workers the reduction of kallikrein production by the kidney is probably responsible for the decreased aldosterone release rather than the opposite, since experiments on isolated rat kidney have shown that aldosterone has no direct effect on kallikrein release. ${ }^{29}$ A study on hypertensive patients and normal subjects did not show that the renin angiotensin aldosterone system directly influences the kallikrein kinin system..$^{30}$ It is therefore possible that $\mathrm{Cd}$ workers whose compensatory reactions to a reduction of kallikrein production are already jeopardised may be at risk of developing hypertension. This study suggests that exposure to Cd alone may not be sufficient to induce hypertension, even in subjects with $\mathrm{Cd}$ induced microproteinuria but it may interact with genetic or acquired conditions that impair other mechanisms of $\overline{\bar{n}}$ blood pressure regulation to stimulate the develop- $\overparen{\mathbb{D}}$ ment of hypertension. Such interactions may be difficult to assess by an epidemiological approach os and may explain why clinical studies on subjects $\overrightarrow{0}$ occupationally or environmentally exposed to $\mathrm{Cd} \overrightarrow{\vec{H}}$ have provided conflicting results. Our observation, $\vec{\omega}$ however, supports the recommendation that subjects $O$ with hypertension should not be exposed to $\mathrm{Cd}$. Monitoring urinary kallikrein activity or concentration might also be useful for the health surveillance of workers exposed to $\mathrm{Cd}$, even in those without $\dot{c}$ microproteinuria.

The present study does not indicate that moderate $ᄋ$ exposure to $\mathrm{Hg}$ or $\mathrm{Pb}$ interferes with renal kallikrein activity. Chmielnicka et al have found a decreased $\bar{z}$ urinary kallikrein activity in $\mathrm{Pb}$ workers with $\mathrm{PbB} \stackrel{\text { }}{\stackrel{2}{2}}$ ranging from 40 to $80 \mu \mathrm{g} / \mathrm{dl} .^{31}$ Boscolo et al reported $\vec{\bullet}$ also a significant decrease in urinary kallikrein activity in workers exposed to $\mathrm{Pb}$ on average for four years and aged more than 33 but they could not detect any significant effect on young exposed workers. ${ }^{32}$ They speculated that with increasing age, the kidney may become more susceptible to damage by $\mathrm{Pb}$. Since in both studies, however, exposure to $\mathrm{Cd}$ which is a frequent contaminant in the $\mathrm{Pb}$ industry $\overrightarrow{\vec{O}}$ was not assessed, ${ }^{31}{ }^{32}$ the possibility that $\mathrm{Cd}$ may have been responsible for the decreased urinary kallikrein found by these authors cannot be excluded. Furthermore, it should be pointed out that the enzymic assay used in these two investigations is based on the esterolytic activity of kallikrein (substrate: $\mathrm{N} \alpha$-benzoyl-L-arginine ethyl ester) which is a less specific assay for this enzyme than the amidolytic assay ${ }^{23}$ used 8 in our study since, in addition to kallikrein, a non- $₹$ kallikrein esterase might contribute to the total 을 esterase activity in human urine. ${ }^{33}$ Since recent $D$ investigations, however, have shown good correlations between human kallikrein activity assays dependent on its enzymatic activity (kinin genera- $\sigma$ tion, S-2266, AcPheArgOEt) and on its immuno- $N$ reactivity (RIA and ELISA), ${ }^{34}{ }^{35}$ the first hypothesis $N$ (concomitant exposure to cadmium) seems more $O$ likely to explain the results of Chmielnicka et $a l^{\beta 1}$ and Boscolo et $a l^{2}$ on workers exposed to lead, although the second hypothesis (interference of non-kallikrein $\stackrel{\mathcal{Q}}{\rightarrow}$ esterolytic activity) cannot be completely ruled out.

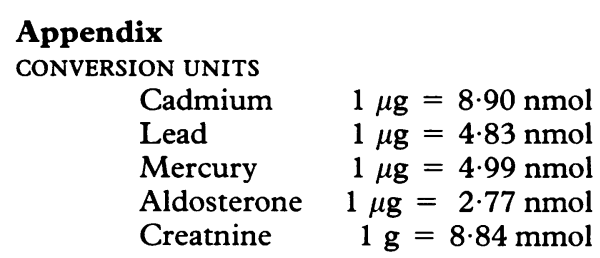

Appendix 
A M Bernard is Chercheur Qualifié du Fonds National Belge de la Recherche Scientifique.

We are grateful to Messrs J Casters, X Dumont, T Seminck, and Miss C Gathy for their skilful technical help.

Requests for reprints to: $\mathbf{R} \mathbf{R}$ Lauwerys, Unité de Toxicologie Industrielle et Médecine du Travail, Catholic University of Louvain, 30.54. Clos Chapelle-aux-Champs, B-1200 Brussels, Belgium.

1 Boscolo P, Galli G, Iannaccone A, Martino F, Porcelli G, Troncone L. Plasma renin activity and urinary kallikrein excretion in lead-exposed workers as related to hypertension and nephropathy. Life Sci 1981;28:175-84.

2 Schroeder HA, Vinton WH. Hypertension induced in rats by small doses of cadmium. Am J Physiol 1962;202:515-8.

3 Perry HM, Erlanger MW. Metal-induced hypertension following chronic feeding of low doses of cadmium and mercury. $J$ Lab Clin Med 1974;83:541-7.

4 Porter MC, Miya TS, Bousquet WF. Cadmium: inability to induce hypertension in the rat. Toxicol Appl Pharmacol 1974;27:692-5.

5 Anonymous. Cadmium, lead, and hypertension. Lancet 1976;ii:1230-1.

6 Loeser E, Lorke D. Semichronic oral toxicity of cadmium I. Studies with rats. Toxicology 1977;7:215-24.

7 Eakin DJ, Schroeder LA, Whanger PD, Weswig PH. Cadmium and nickel influence on blood pressure, plasma renin, and tissue mineral concentrations. Am J Physiol 1980;238:E53-61.

8 Pocock SJ, Shaper AG, Ashby D, Delves T, Whitehead TP. Blood lead concentration, blood pressure, and renal function. Br Med J 1984;289:872-4.

9 Victery W, ed. Symposium on lead-blood pressure relationships, April 27-29, 1987, Chapel Hill, NC. Environ Health Perspect 1988;78:1-155.

10 Carretero OA, Scicli AG. The renal kallikrein-kinin system in human and in experimental hypertension. Klin Wochenschr 1978;56(suppl 1):113-25.

11 Boscolo P, Porcelli G, Carmignani M, Finelli VN. Urinary kallikrein and hypertension in cadmium-exposed rats. Toxicol Lett 1981;7:189-94.

12 Porcelli G, Carmignani M, Boscolo P, Rainieri M, Iannaccone A. Urinary kininase and kallikrein activities and cardiovascular function in rat chronically exposed to cadmium, lead or lead and cadmium. Agents Actions 1982;9:413-8.

13 Girolami JP, Bascands JL, Pécher C, et al. Renal kallikrein excretion as a distal nephrotoxicity marker during cadmium exposure in rats. Toxicology1989;55:117-29.

14 Margolius HS, Horwitz D, Geller RG, et al. Urinary kallikrein excretion in normal man relationships to sodium intake and sodium-retaining steroids. Circ Res 1974;36:812-9.

15 Bernard A, Roels H, Hubermont G, Buchet JP, Masson PL, Lauwerys $R$. Characterisation of the proteinuria in cadmiumexposed workers. Int Arch Occup Environ Health 1976;38: $19-30$.
16 Roels HA, Buchet JP, Lauwerys R, et al. Lead and cadmium absorption among children near a nonferrous metal plant. A follow-up study of a test case. Environ Res 1978;15:290-308.

17 Roels HA, Lauwerys R, Buchet JP, Bernard A. Environmental exposure of cadmium and renal function of aged women in three areas of Belgium. Environ Res 1981;24:117-30.

18 Heinegård $\mathrm{B}$, Tiderström $\mathrm{G}$. Determination of serum creatinine by a direct colorimetric method. Clin Chim Acta 1973;43: 305-10.

19 Bernard AM, Lauwerys RR. Continuous-flow system for automation of latex immunoassay by particle counting. Clin Chem 1983;29:1007-11.

20 Henry RJ. Clinical chemistry: principles and technics. 3rd ed. New York: Harper and Row, 1965.

21 Lauwerys R, Buchet JP, Roels H, Brouwers J, Stanescu D. Epidemiological survey of workers exposed to cadmium: effect on lung, kidney, and several biological indices. Arch Environ Health 1974;28:145-8.

22 Perkin-Elmer. Clinical methods for atomic absorption spectroscopy. Norwalk, CN: Perkin-Elmer, 1971.

23 Bönner G, Marin-Grez M. Measurement of kallikrein activity in urine of rats and man using a chromogenic tripeptide substrate. Validation of the amidolytic assay by means of a bradykinin radioimmunoassay. J Clin Chem Clin Biochem 1981;19:165-8.

24 Malvano R, Orlandini S, Cozzani P, Duranti P, Simonini N, Salvetta A. Methodological simplification of urinary aldosterone. Clin Chim Acta 1976;66:331-43.

25 SAS. Procedures guide for personal computers. Version 6. Cary, NC: SAS Institute Inc, 1985

26 Vio CP, Figueroa CD. Subcellular localisation of renal kallikrein by ultrastructural immunocytochemistry. Kidney Int 1985;28:36-42.

27 Scicli AG, Carretero OA. Renal kallikrein-kinin system. Kidney Int 1986;29:120-30.

28 Öhman KP, Karlberg BE. Urinary kallikrein, aldosterone, prostaglandin $E_{2}$, sodium, potassium, and urinary volume in normal man-interrelations and day to day variation. Acta Med Scand 1983;suppl 677:30-5.

29 Vio CP, Roblero JS, Croxatto HR. Dexamethasone, aldosterone and kallikrein release by isolated rat kidney. Clin Sci 1981;61:241-3.

30 Lawton WJ, Fitz AE. Urinary kallikrein in normal renin essential hypertension. Circulation 1977;56:856-9.

31 Chmielnicka J, Komsta-Szumska E, Szymanska JA. Arginase and kallikrein activities as biochemical indices of occupational exposure to lead. $\mathrm{Br} J$ Ind $\mathrm{Med}$ 1981;38:175-8.

32 Boscolo P, Porcelli G, Cecchetti G, Salimei E, Iannaccone A. Urinary kallikrein of workers exposed to lead. Br J Ind Med 1978;35:226-9.

33 Levinsky NG, Ole-Moi Yoi O, Austen KF, Spragg J. Measurement of human urinary kallikrein and evidence for non-kallikrein urinary TAMe esterases by direct immunoassay and by affinity chromatography. Biochem Pharmacol 1979;28:2491-5.

34 Franke M, Rohrschneider S, Geiger R. Enzyme immunoassay of human urinary kallikrein. J Clin Chem Clin Biochem 1982;20: 621-6.

35 Maier M, Jerabek I, Reissert G, Höltzl E, Binder BR. Correlation of two different assays for urinary kallikrein in normotensive and hypertensive subjects. Clin Chim Acta 1988;178: $127-40$.

Accepted 7 August 1989 